\title{
メニエール病に対するイソソルビド長期治療
}

\author{
野沢出・橋本か拈り・霜村 真一 \\ 菊島一仁・今村まゆみ・今村 俊一 \\ 久松 建一・村上 嘉彦
}

\section{Long-Term Isosorbide Therapy for Meniere's Disease}

\author{
Izuru Nozawa, Kaori Hashimoto, Shin-ichi Shimomura, \\ Kazuhito Kikushima, Mayumi Imamura, Shun-ichi Imamura, \\ Ken-ichi Hisamatsu and Yoshihiko Murakami \\ (Yamanashi Medical College)
}

Isosorbide, an osmotic diuretic, has been used in the medical treatment of Meniere's disease since Kitahara et al first described it in 1980. Since then, there have been several reports on the efficacy of this drug for Meniere's disease, but there have been few long-term clinical evaluations.

The long-term therapeutic effect of Isosorbide was evaluated clinically in 19 patients (9 males and 10 females) followed in our clinic for more than 2 years. Isosorbide was given orally continuously or intermittently for 27 to 183 weeks, depending on each patient's condition. The effectiveness of the drug was determined by the AAOO and AAO-HNS evaluation criteria.

Definite dizzy spells were successfully controlled in $8(73 \%$, according to the AAOO criteria) or 9 (82\%, according to the AAO-HNS criteria) of the 11 patients who received Isosorbide continuously, and in 6 (75\%, according to both criteria) of the 8 patients given the drug intermittently. Hearing improved in $4(21 \%)$ and tinnitus was reduced in 9 (47\%). Among the patients who responded well to treatment, the dosage of Isosorbide could be tapered to a daily dose of $21 \mathrm{~g}(30 \mathrm{ml})$, less than one-third of the usual daily dose of this drug, but in a few patients episodes of vertigo were not well controlled despite continuous medication for more than 6 months.

These results suggest that most patients should continue medical management for several months before a decision can be made that the medical response is good or poor and that the long-term use of Isosorbide is offen effective in stabilizing the disabling symptoms of Meniere's disease.

Key words: Isosorbide, Meniere's disease, therapeutic effect, AAOO, AAO-HNS 
はじめに

メニエール病の薬物療法の一つとして, 浸透 圧利尿剂であるイソソルビドの有効性に関して は多くの報告があり，現在メニエール病に対し てまず最初に用いられる薬となりつつある。し かし，今までの報告は短期観察例が多く，2 年 以上の長期にわたる報告は極めて少なく12), その投与期間，投与量に関しては明確にされて いないのが現状である。

今回我々は，イソソルビドを半年以上投与し, 2 年以上経過観察し得たメニエール病症例に関 して，その治療経過を検討したので, 若干の考 察を加光報告する。

\section{対象と方法}

対象は，1983年10月より1991年10月までの 8 年間化, 山梨医科大学附属病院耳鼻咽喉科めま い外来にて, 厚生省入ニエール病研究班の診断 基準により確実例と診断された19例, 男性 9 例, 女性 10 例で, 年齢は 22 歳から 72 歳までで, 平均 年龄は男性 47.2 歳, 女性 46.8 歳で, 全体では 47.0歳であった(表 1 ).

投与方法は，北野ら ${ }^{3)}$ の方法に準じ，イソソ ルビドを, $120 \mathrm{ml}, 90 \mathrm{ml}, 75 \mathrm{ml}, 60 \mathrm{ml}$ と 1 週 間ごとに順次減量し, 症状の推移により $45 \mathrm{ml}$,

表 1 対 象

\begin{tabular}{c|c|c|c}
\hline \hline & 男 性 & 女 性 & 合 計 \\
\hline $\begin{array}{c}\text { メニェール病 } \\
\left(\begin{array}{c}\text { (確実例) } \\
\text { 平均年齢 }\end{array}\right.\end{array}$ & 9 例 & 10 例 & 19例 \\
\hline 4.2歳 & 46.8 歳 & 47.0 歳
\end{tabular}

表 2 投与方法と投与期間

\begin{tabular}{c|c|c}
\hline \hline 投与法 & 継続投与群 & 断続投与群 \\
\hline 半年以上 1 年未満 & 3 & 4 \\
1 年以上 2 年未満 & 6 & 0 \\
2 年以上 & 2 & 4 \\
\hline 合 計 & 11 例 & 8 例
\end{tabular}

$30 \mathrm{ml}$ と減量もしくは継続投与したが，その方 法は症例により適宜変更した。

投与期間は，継続投与群では，半年以上 1 年 未満が 3 例， 1 年以上 2 年末満が 6 例， 2 年以 上が 2 例, 断続投与群では, 半年以上 1 年未満 が 4 例， 1 年以上 2 年末満が 0 例， 2 年以上が 4 例であり, 投与期間を週数で示すと, 27 週か ら183週であり, 平均80.3週であった（表 2$)$.

\section{結果}

1 ）治療効果判定基準とその成績

めまいに対する治療効果判定には, AAOO およびAAO-HNSの判定基準を用いた。 AAOO の判定基準では, 継続投与群では, class A 3 例, class B 4 例, class C 1 例, class D 3 例で有効率 $73 \%$, 断続投与群では, class A 1 例, class B 5 例, class C 0 例, class D 2 例であり，有効率 $75 \%$ であった.

AAO-HNS の判定基準では, 継続投与群で は, 完治 2 例, 有効 5 例, やや有効 2 例, 不変 2 例, 悪化 0 例で, 有効率 $82 \%$, 断続投与群で

表 3 めまいに対する治療効果判定 一 AAOO の判定基準一

\begin{tabular}{|c|c|c|}
\hline 評 価 投与法 & 継続投与群 & 断続投与群 \\
\hline class A & 3 & 1 \\
\hline class B & 4 & 5 \\
\hline class $\mathrm{C}$ & 1 & 0 \\
\hline class $\mathrm{D}$ & 3 & 2 \\
\hline 合 計 & 11例 & 8 例 \\
\hline
\end{tabular}

—AAO-HNS の判定基準—

\begin{tabular}{|c|c|c|}
\hline 評 価 投与法 & 継続投与群 & 断続投与群 \\
\hline 完 治 & 2 & 0 \\
\hline 有 効 & 5 & 4 \\
\hline やや有効 & 2 & 2 \\
\hline 不 変 & 2 & 1 \\
\hline 悪 化 & 0 & 1 \\
\hline 合 計 & 11例 & 8 例 \\
\hline
\end{tabular}


は, 完治 0 例, 有効 4 例, やや有効 2 例, 不変 1 例, 悪化 1 例で, 有効率 $75 \%$ であった(表 3 ).

2 ) 耳鳴, 聴力障害に対する効果と維持量

耳鳴に対しては，患者自身の自覚的訴えより 判定し, 消失 3 例, 軽快 6 例, 不変 9 例, 悪化 1 例であり, 全体で $47 \%$ の有効率であった。

聴力に対しては，今回は，実際に得られた聴 力検査成績から， $500,1000,2000 \mathrm{~Hz}$ の 4 分法 を用いて検討し，治療後18～24力月間で最も悪 化した時と治療前 6 力月間で最も悪化した時の 聴力をそれぞれ比較したところ，平均 $10 \mathrm{~dB}$ 以上の改善を示したのは 4 例, 不変10例, 悪化 5 例で，21\%の有効率であった(表 4 ).

また，現在も本剤投与中の14例についての維 持量に関しては， $30 \mathrm{ml} 3$ 例， $45 \mathrm{ml} 2$ 例， 60 $\mathrm{ml} 4$ 例, $75 \mathrm{ml} 3$ 例, $90 \mathrm{ml} 2$ 例であり, 少量 投与でも回転性めまい発作がコントロールされ ている症例がみられた（表 5 ).

3 ) 長期投与症例 ( 2 年以上)の検討結果

さらに，2 年以上の長期にわたりイソソルビ ドを投与している 6 例について検討した.

結果は下記の通りである.

症例 1 は, 22 歳, 女性. 左メニエール病症例 で，118週間，断続投与した. $30 \sim 60 \mathrm{ml}$ の量 で投与中に数回，回転性めまい発作が出現した ため，コントロール不良と判断し，患者と相談 の上，坂田）の方法に準じ， $4 \%$ 塩酸リドカイ ンの鼓室内注入療法を施行した。AAOO の判 定基準では class D，AAO-HNS では不変であ った。

症例 2 は, 68歳, 女性. 右メニエール病症例 で，142週間，継続投与した． $75 \mathrm{ml}$ で 1 度回 転性めまい発作が出現したが，その後は発作が 出現しないため，現在は $90 \mathrm{ml} て ゙$ 継続投与中で ある. AAOO の判定基準では class B， AAOHNS では有効であった.

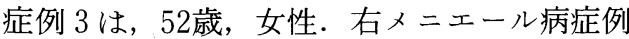
で，154週間，断続投与した。投与終了後 6 力 月と 8 カ月に， 2 度回転性めまい発作が出現し， 現在も $60 \mathrm{ml}$ の維持量で投与中である. AAOO
の判定基準では class B，AAO-HNS ではやや 有効であった。

症例 4 は，59歳，女性. 両側メニエール病症 例で，158週間，断続投与した。投与終了後 3 カ月に，また $30 \mathrm{ml}$ 抌よび $60 \mathrm{ml}$ 投与中にも回 転性めまい発作を繰り返すため，コントロール 不良と判断し，患者と相談の上， $4 \%$ 塩酸りド カインの鼓室内注入療法を施行した。 AAOO は class D, AAO-HNS は不変であった。

症例 5 は, 32歳, 女性. 左メニエール病症例 で，158週間，断続投与した．投与終了後，2 週間および 6 力月に回転性めまい発作が出現し たため， $60 \mathrm{ml}$ を継続投与中であるＡAOO の

表 4

耳鳴に対する治療効果判定

\begin{tabular}{cc|c}
\hline \hline 評 & 価 & 例 \\
\hline 消 & 数 \\
軽 & 快 & 3 \\
不 & 変 & 6 \\
悪 & 化 & 9 \\
合 & 計 & 1 \\
\hline
\end{tabular}

聴力に対する治療効果判定

\begin{tabular}{cc|c}
\hline 評 & 価 & 例 \\
\hline 数 \\
\hline 不 & 善 & 4 \\
変 & 10 \\
悪 & 化 & 5 \\
\hline 合 & 計 & 19 例
\end{tabular}

表 5 維持量の検討

\begin{tabular}{c|c}
\hline \hline 維 持 量 & 例 数 \\
\hline $30 \mathrm{ml}$ & 3 \\
$45 \mathrm{ml}$ & 2 \\
$60 \mathrm{ml}$ & 4 \\
$75 \mathrm{ml}$ & 3 \\
$90 \mathrm{ml}$ & 2 \\
\hline 合 計
\end{tabular}


判定基準では class C，AAO-HNS では有効で あった。

症例 6 は, 62歳, 男性. 左メニエール病症例 で，183週間，継続投与した. $15 \mathrm{ml}$ の投与量 の際と投与中止直後に回転性めまい発作が出現 し，現在 $30 \mathrm{ml}$ で継続投与中である.AAOO の判定基準では class C, AAO-HNS では有効 であった(表 6 ).

聴力に関しては， 4 例が不変， 2 例が悪化で, 耳鳴に関しては 1 例が消失， 3 例が軽快， 2 例 が不変であった(表 6 )。グリセロールテストは， 5 例で陽性であり, 全例がめまい発作のために 何度か入院の既往があり重症例が多かった。

\section{考按}

イソソルビドは，1927年 Muller と Hoffman によって，初めて合成された物質で， 6 価の糖 アルコールである D-ソルビトールから 2 分子 の水が脱水された物質である. そして，経口投 与により速やかに吸収され，体内に打いて代謝 されず24時間で注とんど尿中に排泄され，血清 浸透圧を高め, その結果, 利尿作用, 脳圧降下 作用, 眼圧降下作用, 内リンパ圧降下作用を示 す.

また，実験的にも，1965年 Treon ら5)は， イヌにイソソルビドを投与し, 本物質が浸透圧 利尿作用を有することを報告した．

メニエール病に対しても, 北原6), 矢沢788) ら は，モルモットに打いて実験的内リンパ水腫を
作製しイイソソルビドを経口投与として 75 $\mathrm{W} / \mathrm{V} \%$ 液 $4 \mathrm{ml} / \mathrm{kg}(3 \mathrm{~g} / \mathrm{kg} ， 1$ 日人体投与量の 約 2 倍相当)，静脈内投与として $85 \mathrm{~W} / \mathrm{V} \%$ 液 $1.6 \sim 2.2 \mathrm{ml} / \mathrm{kg}(1.36 \sim 1.87 \mathrm{~g} / \mathrm{kg}$ ，1 日人体投 与量に汪湆相当)を投与し, 対照群と比較して, 有意にライスネル膜の伸展と水腫の軽減が認め られ，前庭内リンパ系の水腫に対しても有意に 軽減が認められたとし，その作用機序として， 形質孔の直径より小さい径をもつイソソルビド の分子は, 容易に血管条の辺縁細胞に移行し, その浸透圧を上昇させる，そこで生じた内リン パ液との浸透圧勾配によって，内リンパ液の吸 収が起こるとしている。そしてその働きは，グ リセオールに注汇敵するもので，その内リン パ水腫軽減作用は十分評価に值するものである と報告した。 また，最近矢沢ら ${ }^{9}$ は，さらにレー ザードップラー法を用いて，イソソルビドを $1.6 \mathrm{ml} / \mathrm{kg}$ 投与し, 内リンパ鞟扣よび蝸牛壁血 流变化を検討し，内リンパ豊血流に対しては約 1.8倍, 蝸牛壁血流に対しては約 1.6 倍の血流の 増加作用のあることも報告している。

本製剤の組成は， $100 \mathrm{ml}$ 中にイソソルビド を $70 \mathrm{~g}$ 含んで拈り, 臨床的には, 通常成人 1 日量として $70 \sim 140 \mathrm{ml}$ を $2 \sim 3$ 回に分けて経 口投与し, 脳腫瘍時の脳圧降下, 頭部外傷に起 因する脳圧充進時の脳圧降下，腎尿細管結石時 の利尿, 緑内障時の眼圧降下, メニエール病の 内リンパ水腫の軽減などを目的として，その治

表 6 イソソルビドの長期投与例 ( 2 年以上)の検討

\begin{tabular}{|c|c|c|c|c|c|c|c|c|c|c|}
\hline 症例 & $\begin{array}{l}\text { 年㱓 } \\
\text { (歳) }\end{array}$ & 性別 & 患側 & $\begin{array}{l}\text { 投与方法と } \\
\text { 期間(週間) }\end{array}$ & $\begin{array}{c}\text { めまい発作 } \\
\text { 出現時の量 } \\
(\mathrm{ml})\end{array}$ & $\begin{array}{c}\text { 維持量 } \\
(\mathrm{ml})\end{array}$ & AAOO & AAO-HNS & 聴力 & 耳鳴 \\
\hline 1 & 22 & 女 & 左 & 断続 118 & $30 \sim 60$ & & $\mathrm{D}$ & 不変 & 不変 & 不変 \\
\hline 2 & 68 & 女 & 右 & 継続 142 & 75 & 90 & B & 有効 & 不変 & 消失 \\
\hline 3 & 52 & 女 & 右 & 断続 154 & 0 & 60 & B & やや有効 & 不変 & 不変 \\
\hline 4 & 59 & 女 & 両 & 断続 158 & $0 \sim 60$ & & $\mathrm{D}$ & 不変 & 不変 & 軽快 \\
\hline 5 & 32 & 女 & 左 & 断続 158 & 0 & 60 & $\mathrm{C}$ & 有効 & 悪化 & 軽快 \\
\hline 6 & 62 & 男 & 左 & 継続 183 & $0 \sim 15$ & 30 & $\mathrm{C}$ & 有効 & 悪化 & 軽快 \\
\hline
\end{tabular}

（空白は他治療へ変更したことを示す） 
療に用いられている。

メニエール病に対するイソソルビドの治療効 果に関しては臨床的にも多くの報告があ り1) 3)10) 17)，めまいに対しては68～91\%の 有効率とされるが，その多くは短期観察例であ る. 北野ら ${ }^{3) 111}$ は, 短期の観察症例ではめまい に対して $91 \%$ の有効率であるが， 1 年以上の観 察例では，めまいに対して $68 \%$ の有効率とし， 投与開始後 6 力月以内に回転性めまい発作が再 発しない症例では， 1 年以上でも起こりにくい が，そのコントロールのためには長期に連用し なくてはならないとしている，我々の症例も同 様で，長期投与症例は，短期投与症例と比較し て結果的に重症例が多く，めまい発作は投与前 に比べてコントロールされているが，発作予防 のためには長期投与せざるを得ない状態となっ ている. また, 将積ら゙) は, 2 年以上の長期観 察で AAO-HNS の判定基準により $84 \%$ の有効 率が得られたとし，イソソルビドは，短期だけ でなく長期にわたりめまい発作を軽減できると 報告している.

聴力に対しては 7 29\%の有効率であり, 我 我の症例も含めて, 聴力に関してはあまり効果 的でないといら報告が多いが，報告者によって その判定法も自覚的訴光による評価と純音聴力 検査による定量的評価によるものとがあり，一 定していない，乙たがって，以前著者ら吕が報 告したように自覚的に改善していると患者が訴 えていても，実際に純音聴力検査を施行すると 改善していない場合もあることも考慮しなくて はならない, 一方, 最近田矢ら ${ }^{17)}$ は, メニェー ル病症例にイソソルビドを 1 日 $90 \mathrm{ml}$ 投与し, 聴力の改善した例が多いと報告している．ただ し, 投与期間, 観察期間, 判定基準の問題など もある上, メニエール病の聴力は, 上く知られ ているよらにしばしば変動することが多いので, 今後長期にわたり観察し検討する必要があるも のと思われる.

耳鳴に対しては，15〜67\%の有効率で，報告 者により差が大きい。北野ら ${ }^{11)}$ は, 短期执よ
び中期観察では，それぞれの有効率は $66 \%$ と72 \%であったのに対し， 1 年以上では $31 \%$ と報告 している. 一方, 将積ら ${ }^{1)}$ は， 2 年以上の観察 で耳鳴に対する有効率は15\%とし, 報告により 差異があるのは観察対象の相違も考光られるが, メニエール病長期化による難聴の進行を完全に 防止できないことと平行して，それに付随して 耳鳴も改善しない可能性があるために有効率が 低いとしている. 我々の症例では， 2 年以上の 長期観察例でも $47 \%$ と耳鳴に対する有効率が高 いのは，あくまで患者自身の自覚的訴えからの 判定であるために，長期経過することにより患 者自身の耳鳴に対する慣れの問題が生じてくる ものとも考兄られ, 耳鳴の判定の困難さも考慮 する必要があるものと思われる(表 7 )。したが って，今後はさらに自覚的な訴えによる評価の みでなく, 他覚的評価としてのピッチマッチ検 查, ラウドネスバランス検査, 遮蔽検査等も施 行し，ょり客観的に検討する必要性を示唆する ものであると考えられる。

投与量に関しては，メニエール病の場合は, 1 日 $1.5 \sim 2.0 \mathrm{ml} / \mathrm{kg}$ として, $90 \sim 120 \mathrm{ml}$ を毎 食後 3 回に分けて経口投与するのが適当とされ ている. 北原ら ${ }^{10)}$ は, 92例のメニエール病に 対する用量検討試験で，投与期間が 4 週間，観 察期間が 2 週後拉よび 4 週後での判定で検討し， めまい全体を通しての改善度やめまいの性質に 対する改善度に関しては, $120 \mathrm{ml}$ 投与群が 30 $\mathrm{ml}$ 投与群を有意に上回り, 随伴症状全体を通 しての改善度は, $90 \mathrm{ml}$ 投与群の改善度の方が $30 \mathrm{ml}$ 投与群のそれょりも有意に上回り, 以上 の結果から，イソソルビドの 1 日あたりの至適 投与量と用法は，副作用も考无合わせると， $120 \mathrm{ml}$ よりも $90 \mathrm{ml}$ とし, 毎食後 3 回に分け 経口投与するのが望ましいと判断している．野 地ら ${ }^{16)}$ は，入院したメニエール病患者 90 例に 対して，イソソルビドの 1 日投与量を 45〜90 $\mathrm{ml}$ とし，投与観察期間を 7 日から 351 日間とし て検討したところ，すべての投与量で $80 \%$ 近く のめまい発作の抑制率を得たとし，60,45 ml 
と漸減するに従い若干抑制率が低下する傾向が 認められたとしている。そして，回転性めまい 発作, 非回転性めまい発作, 頭痛, 頭重感が主 な症例では，1日 $90 \mathrm{ml}$ または $120 \mathrm{ml}$ を開始 量とし，次いで， $75 \mathrm{ml}$ の中等度量を維持量と して相当期間投与するのが望ましいとしている. また，厚生省特定疾患前庭機能異常研究班の メニエール病に対するイソソルビド使用のため の参考資料(表 8 ) では，使用の対象として，め まい頻発例とグリセロール試験陽性例には特に 有効とし，60〜90 $\mathrm{ml}$ 投与が適量であって，1 日 $30 \mathrm{ml}$ 程度では効果が少ないとしている。 た，服用に際して患者が飲みにくいとする欠点 に対しては，氷で冷やしたり，レモンで味付け したりするが，また液を薄める場合もあるが， $3 \sim 4$ 回服用後には患者は比較的容易に服用で きるようになると記してある。

しかし，現実問題として 2 年以上の長期にわ たり服用している我々の症例でも，慣れたとは いえその服用しづらさを訴えていることも事実 である。また，19例中 6 例は，指示に従わずに 服用を中止し，その結果とみられる回転性めま い発作を再度起こして受診してきていた。この
ことを考光わせると，我々の症例で，現在イ ソソルビドを継続投与中の 14 例中 5 例 $(36 \%)$ に おいて， $30 \mathrm{ml}$ 抢よび $45 \mathrm{ml}$ という少量でもめ まい発作をコントロールできているということ は，症例を選べば，長期少量持続投与といら治 療方法も考慮してもよいものと思われる. しか し， $30,45 \mathrm{ml}$ という少量ではたしてメニェー ル病の内リンパ水腫に対して, その軽減効果が 実際に期待できるのかといら疑問が残ることも 事実であるが，これを考学る理由としては，

1) 個人差の問題, 2) メニエール病の病期 との関連性，3）心理的な問題, その他が考兄 られる。

1 ) 個人差の問題としては, 北原ら 10$)$ が, 1 日量 $30 \sim 45 \mathrm{ml}$ の少量投与でも, 軽度以上の 改善が 2 週間後で $26.1 \%, 4$ 週間後で $30.4 \%$ に みられたとしているように，同じ量を投与して も内耳一の移行性もしくはそのほかの理由によ る有効性が個人により異なる可能性が考えられ る。

2) メニェール病の病期との関連性では, 活 動期と非活動期では，積極的に治療する場合の 投与量と，予防的に治療する場合のそれとの間

表 7 メニエール病の 3 主要症状に対するイソソルビドの有効率と投与量, 投与期間の関係

\begin{tabular}{|c|c|c|c|c|c|c|c|c|}
\hline 報 告 者 & 対象 (例数) & 年㱓(歳) & $\begin{array}{c}\text { 投与量 } \\
(\mathrm{ml})\end{array}$ & 投与期間 & 観察期間 & めまい $(\%)$ & 聴力 (\%) & 耳鳴 (\%) \\
\hline 北野ら（1981） & 52 & & $30 \sim 90$ & & & 91 & & 66 \\
\hline 山崎ら（1981） & 14 & & 70 & 3 日〜 1 力月 & 6.7 力 & 71 & & \\
\hline 石川ら（1983） & 22 & $41 \sim 71$ & 90 & 6 週 20 週 & & 83 & 20 & 31 \\
\hline 北野ら（1983） & 66 & $32 \sim 72$ & $45 \sim 90$ & 6.1力月 (平均) & 1 年以上 & 68 & 13 & 36 \\
\hline 草刈ら（1984） & 14 & $29 \sim 59$ & 70 & 21 日～78日 & & 71 & 7 & 36 \\
\hline 調 (1985) & 25 & $27 \sim 66$ & 90 & 4 週 & & 84 & 32 & 36 \\
\hline 北原ら（1987） & 57 & $23 \sim 65$ & $50 \sim 140$ & 4 日～449日 & 51 日 & 83 & 29 & 48 \\
\hline 野地ら（1987） & 90 & $22 \sim 74$ & $45 \sim 90$ & 7 日～351日 & 1.3日 & 83 & & 67 \\
\hline 将積ら（1988） & 19 & $36 \sim 65$ & 90 & & 2 年以上 & 84 & 26 & 15 \\
\hline 野沢ら（1992） & 43 & $14 \sim 72$ & $30 \sim 120$ & 6 週 8 週 & 8 週 & 86 & 21 & 43 \\
\hline 野沢ら（1993） & 19 & $22 \sim 72$ & $30 \sim 90$ & 27 週 183週 & 2 年以上 & 79 & 21 & 47 \\
\hline
\end{tabular}

（空白は，明確に記載されていないことを示す） 
に，有効性を発揮するための投与量として量的 に差がある可能性も考えられる。

3 ）心理的な問題としては，長期投与してい る症例は, メニエール病に対してイソソルビド が効果のあることを自覚している患者が多く， 有効量とはいえないような少量でも，それを服 用していることが回転性めまい発作に対して効 果的であると思い込んでいる可能性もあるもの と考光られる。事実, 回転性めまい発作の出現

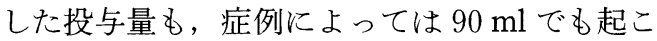
る場合もあり，長期投与症例に対しては，個々 の患者の自覚的訴之と他覚的所見を十分に観察 しながらイソソルビドの投与量を決定すること が望ましいと思われる。

さらにもら一つの大きな問題としては, イソ ソルビドの投与をいつ終了するかといらことで ある、今までは，投与量に関しての報告はあ

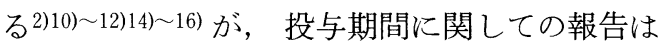

汪とんどない。田矢ら 17)は, 聴力改善の時期 を目安として，投与開始後 2 週ないし 1 力月で イソソルビドの投与を継続するかどらかを決め るのがよいとしている. 我々は, 以前 2 年以上 観察し得た症例に拈いて AAOOでは，半年以 上投与群 $69 \%$, 半年以内投与群 $91 \%, \mathrm{AAO}$ HNS では，半年以上投与群 $77 \%$ ，半年以内投 与群 $91 \%$ の有効率であり, 半年以上投与群で有 効率が低下寸るのは重症例が多いためであるこ とを報告した2)．以上より考光てみると 1 力月 を投与持続，半年を投与終了するか否かの目安 として, 他の治療法や薬物に変更もしくは併用 を考慮するのも一つの方法であると思われる。

今回，イソソルビドのメニエール病に対する 効果を AAOO および AAO-HNS の判定基準に よって報告した。特に, AAO-HNS の判定基 準では 2 年以上の長期にわたって観察しなけれ ばならず，また，本症の様な慢性疾患において

表 8 メニエール病に対するイソソルビド使用のための参考資料

1. 使用の対象

メニエール病, いわゆる続発性内リンパ水腫など.すなわち内リンパ水腫の推定さ れる症例に有効であるが，中でもめまい頻発例，グリセロール試験陽性例は特に有効 とされている。単なるめまい症例は有効な使用対象例とならない。

2 . 投与量

体重 $60 \mathrm{~kg}$ を標準として $70 \mathrm{~W} / \mathrm{V} \%$ のイソソルビドを含む水溶液 90〜 $120 \mathrm{ml}$ を 1 日量とし，3 回に分け投与する.しかし $120 \mathrm{ml}$ は胃もたれ等の副作用のでることも 多いので，60 90 $\mathrm{ml}$ 投与が普通である. 1 日 $30 \mathrm{ml}$ 程度の投与では効果は少ない.

3 . 投与方法

一般に 4 週間以上長期連続投与を行ら。年余にわたり投与する場合もあるが，この 場合は症状にあわせ投与量を加減する，発作を予防する意味でのめまい前兆時にのみ 投与する場合もある.

4. 副作用と副作用防止のための対策

消化器症状 (胃もたれ, 胸やけ, 腹部膨満, 便秘など)が主体である.イソソルビド は一般に食後投与されるが，食前投与でもよい，飲みにくい人には，氷で冷やしたり， レモンの味を付けたり，70 W/V\% 液を薄める場合もある。しかし，その様なことを せずとも，3〜4 回服用後には容易に飲めるようになることが多い. 電解質異常は長 期投与でもまず見られないが，定期的な血液検査が望ましい，急性頭蓋内血腫には投 与しない。また脱水状態，腎機能障害，罾血性心不全には慎重に投与する.

5. 備 考

グリセオール試験でグリセオールの代わりにイソソルビド $120 \mathrm{ml}$ を使用すること もある・ 
薬物の効果を判定するにはなるべく長期にわた り投与寸る必要があり，多忙な日常臨床ではそ の正確な効果判定は，必ずしも容易ではないこ とも事実である. 事実, 二木 ${ }^{18)}$ はメニエール 病患者の場合， 3 力月を経過すると患者が受診 しなくなるか，他の治療方法に变更する必要が あり, その治療経過の追求がかなり困難なこと があると指摘している. 我々もイソソルビドを メニェール病の治療のためにこれまで61例に投 与してきているが，半年以上投与し，かつ 2 年 以上経過観察し得たのは19例 $(31 \%)$ 飞止まって いるのが現状である. したがって, 特に薬物療 法に上る治療効果判定の場合, その長期観察の 困難さも考慮し, 将積ら1) も述べているように, 薬物の投与期間, 投与量も含めて, 今後はより 現実的, 実際的な効果判定基準を検討する必要 があるものと思われた。

\section{まとめ}

メニエール病確実例19例(男性 9 例, 女性10 例)にイソソルビドを半年以上投与し， 2 年以 上経過観察し得た症例について検討し, 以下の 結果を得た。

1）投与期間は 27 週から 183 週であり，平均 投与期間は 80.3 週であった。

2 ) AAOO の判定基準では，継続投与群で $73 \%$, 断続投与群では75\%の有効率であり,

AAO-HNS の判定基準では, 継続投与群で82 $\%$, 断続投与群では $75 \%$ の有効率であった.

3 ）耳鳴に関しては $47 \%$ の有効率, 聴力に関 しては21\%の有効率であった。

4 ) 長期投与例 ( 2 年以上) では, 回転性めま 、発作を継続投与中もしくは, 投与終了後にも 起こす例があり, 結果的に重症例と判定される 症例が多かった。

5 ）投与維持量に関しては, 個々の症例によ りその投与量を決定するのが望をしいと思われ た。

本論文の要旨は, 第 50 回日本平衡神経科学会(横浜) で発表した.

\section{参考文献}

1）将積日出夫, 水越鉄理, 麻生 伸, 他 : メエー ル病の長期間観察例の推移 -AAO-HNS の判 定基準による Isosorbide の治療効果について 一. Equilibrium Res $47: 120 \sim 123,1988$.

2) 野沢 出, 今村俊一, 村上嘉彦, 他 : メニエー ル病の保存的治療に対する検討 一イソソルビ ドの使用経験一. Equilibrium Res 51:260 264, 1992.

3）北野博也, 南 文香 : メニエール病に対する Isosorbide の効果 -1 年以上の観察例につい て一. 耳鼻臨床 $76: 2737 \sim 2740,1983$.

4）坂田英治：キシロカインならびにステロイド剂 鼓室内注入による耳鳴の治療. 耳鼻臨床 76 : 3052 3055, 1983.

5) Treon JF, Congwer LE and Rueggeberg WHC : Isosorbide, a new oral osmotitic diuretic. Proc Soc Exp Biol Med $119:$ 39 42, 1965.

6) 北原正章 : メニェール病の基礎と臨床. 第82回 日本耳鼻咽喉科学会総会宿題報告. 1359頁, 1981.

7) 矢沢代四郎：内リンパ水腫に関する組織学的研 究. 耳鼻臨床 74 増 $5: 2450 \sim 2506,1981$.

8）矢沢代四郎：内リンパ裹硝酸銀腐蝕法により作 製したモルモット実験的内リンパ水腫に対する イソソルビド, グリセロール, フロセミドの影 響. 薬理と治療 $13: 275 \sim 284,1985$.

9）矢沢代四郎, 北原正章 : 浸透圧利尿剂等に関す るモルモット内リンパ裹血流に対する変化.

Otology Japan 2 : 76, 1992.

10）北原正章, 渡辺勈, 水越鉄理, 他 : Isosorbide のメニエール病に対する用量検討試験.

薬理と治療 $15: 2975 \sim 2990,1987$.

11）北野博也, 斎藤春雄, 北嶋和智 : メニエール病 に対する薬物学的減荷について. 耳鼻臨床 74 増 $5: 2406 \sim 2412,1981$.

12）草刚潤, 鈴木 茂, 河本和友: メニエール病 に対するイソソルビドの効果について.耳萛臨 床 $77: 2443 \sim 2451,1984$.

13）石川保之, 中西和二：メニエール病に対するイ ソソルビドの使用経験. 耳鼻臨床 $76: 2177$ 2186, 1983.

14）調 重昭：メニエール病に対寸る高浸透圧利尿 剤イソソルビドの適用について.耳鼻 31 : 
1017 1022, 1985.

15）山崎 勤, 林奈美江, 渡辺幸枝, 他 : x =エー ル病とイソソルビド(経口高浸透圧利尿剂) 一 臨床蝸電困による効果判定一. 耳鼻 $27: 559$ 569, 1981.

16）野地あ扒い，北野博也，北原正章：メニエール 病に対するイソソルビドの Dosis についてー イソソルビドの効果一. 薬理と治療 $15: 547$ 551, 1987.

17）田矢直三, 武田憲昭, 肥塚 泉, 他 : イソソル ビドのメニエール病の難聴に対する効果. 第50
回日本平衡神経科学会総会学術講演会プログラ 么予稿集. 221頁, 1991.

18）二木 隆：メニエール病の治療効果判定につい

て. Equilibrium Res $46: 238 \sim 248,1987$.

$\left(\begin{array}{c}\text { 原稿受付: 平成 } 4 \text { 年 } 6 \text { 月 } 3 \text { 日 } \\ \text { 原稿採択 : 平成 } 4 \text { 年 } 8 \text { 月 } 19 \text { 日 } \\ \text { 別刷請求先: 野沢 出 } \\ \text { 干409-38 山梨県中巨摩郡玉穂町 } \\ \text { 下河東 } 1110 \\ \text { 山梨医科大学耳鼻咽喉科学教室 }\end{array}\right)$

